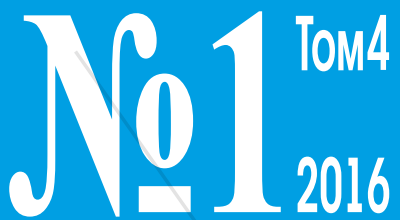

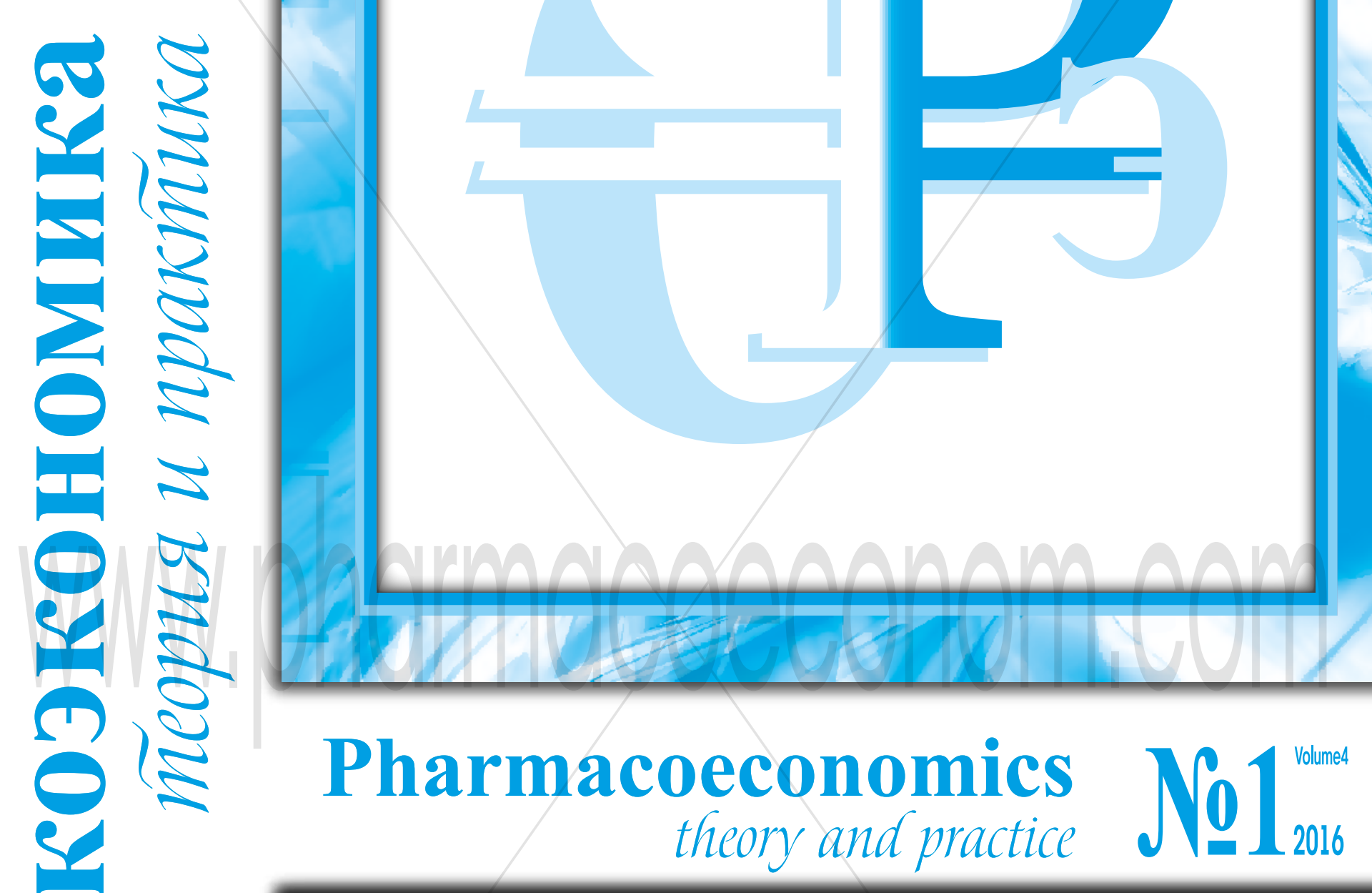

$\square$ МЕТОДОЛОГИЧЕСКИЕ ОСНОВЫ ФАРМАКОЭКОНОМИЧЕСКОГО МОДЕЛИРОВАНИЯ

$\square$ РЕЗУЛЬТАТЫ РОССИЙСКИХ ФАРМАКОЭКОНОМИЧЕСКИХ ИССЛЕДОВАНИЙ

口 МАТЕРИАЛЫ Х НАЦИОНАЛЬНОГО КОНГРЕССА С МЕЖДУНАРОДНЫМ УЧАСТИЕМ «РАЗВИТИЕ ФАРМАКОЭКОНОМИКИ И ФАРМАКОЭПИДЕМИОЛОГИИ В РОССИЙСКОЙ ФЕДЕРАЦИИ» 4-5 апреля 2016 г., г. Нижний Новгород 


\title{
PHARMACOECONOMIC ANALYSIS OF MEDICINAL DRUG FOSINOPRIL IN PATIENTS WITH ARTERIAL HYPERTENSION
}

\author{
Tolordava G. A., Arinina E.E., Kulikov A.Yu.,
}

\section{I.M. Sechenov First Moscow State Medical University of the Ministry of Health of the Russian Federation}

\begin{abstract}
:
Blockade of renin-angiotensin system (RAS) remains one of the most main strategies in treatment of arterial hypertension (AH), and drugs blocking this system, mainly angiotensin-converting-enzyme inhibitor (ACEI) and blockers of receptors to angiotensin II, are the main classes of antihypertensive drugs. The presence of different clinical effectiveness of drugs in these groups, as well as different frequencies of occurrence of undesirable cardiovascular events, side effects and formed the basis of pharmacoeconomic (PE) studies.

According to the conducted cost-effectiveness analysis, the treatment regimen using Monopril is characterized by lowest cost and the lowest coefficient of cost-effectiveness ratio in the treatment of patients with $\mathrm{AH}$. The results of the budget impact analysis suggest that therapy with Monopril leads to budget savings. The results of the sensitivity analysis demonstrated the adequacy of the performed pharmacoeconomic analysis and the stability of the obtained data during the change of the cost factors in the range of $\pm 97 \%$ the therapy with the drug Monopril maintained its advantage expressed by the results of the cost-effectiveness analysis. Cost-effectiveness analysis and budget impact analysis were used in this study. The indirect comparison of two antihypertensive drugs was performed: ACEI (fosinopril, ramipril, lisinopril, perindopril) and ARB II (valsartan, losartan, telmisartan, candesartan). Both groups of drugs are not only one of the main classes of antihypertensive drugs, which can be prescribed to all patients with $A H$, but also have priority indications, such as diabetes mellitus, metabolic syndrome etc. Results of costs analysis show that fosinopril treatment scheme is characterized with total costs - 22751 rub., with the lowest cost-effectiveness ratio - 285, during the treatment of $\mathrm{AH}$ and budget economy from 5048 rub. to 46805 rub. per 1 person per year compared with-ramipril, lisinopril, perindopril, valsartan, losartan, telmisartan, candesartan.
\end{abstract}

Key words: ACEls, ARB, RAAS, fosinopril, ramipril, lisinopril, perindopril, valsartan, Iosartan, telmisartan, candesartan, arterial hypertension, infarction, stroke, cardiovascular diseases, , budget impact analysis, cost-minimization analysis, cost analysis, pharmacoeconomics.

\section{Введение}

Cardiovascular diseases are the leading cause of death in Europe and account for over 4.3 million deaths each year. Arterial hypertension $(\mathrm{AH})$ is the leading risk factor for cardiovascular (myocardial infarction, stroke, coronary heart disease, chronic heart failure), cerebrovascular (ischemic or hemorrhagic stroke, transient ischemic attack) and kidney diseases (chronic kidney disease). Cardiovascular and cerebrovascular diseases, represented in official statistics, as of cardiovascular system diseases (CVD) are the leading causes of population mortality in the Russian Federation, their share in the number of deaths from all causes accounts for more than $55 \%$ of deaths [31-34]. In modern society there is a significant prevalence of $\mathrm{AH}$, accounting for $30-45 \%$ of the adult population according to foreign studies and about $40 \%$ according to Russian studies. In Russian population the prevalence of $\mathrm{AH}$ among men is slightly higher in some regions it reaches $47 \%$, whereas among women the prevalence of $\mathrm{AH}$ is about $40 \%$. [43]

Renin-angiotensin-aldosterone system (RAAS) is considered as the main factor regulating blood pressure and homeostasis, it plays a central role in the occurrence of $\mathrm{AH}$ and its consequences, serves as an indispensable participant in the cardiovascular continuum starting with risk factors, the potentiation of atherosclerosis, endothelial dysfunction, ischemic heart disease (IHD), left ventricular hypertrophy, myocardial remodeling and final heart failure and chronic kidney disease (CKD) [35-39].

Currently, the treatment of hypertension in Russia is conducted on the basis of the clinical recommendations of the Russian Ministry of health for the diagnosis and treatment of hypertension from 2013, which recommended the 5 main classes of antihypertensive drugs: angiotensin-converting-enzyme inhibitors (ACEls), Angiotensin II Receptor Blocker II (ARB), calcium channel blocking agents (CCBA), beta-blocking agent (BBA), diuretics [34]. The change in RAAS activity is possible on the background of antihypertensive therapy. One way of reducing the activity of RAAS is the suppression of synthesis of angiotensin II [41,42].

The purpose of this study is to determine, from the perspective of a pharmacoeconomic analysis of preemptive medications used for the treatment of hypertension based on the comparison between cost and efficiency, safety and quality of life in the treatment of drugs of two classes of antihypertensive drugs ACEIs: Fosinopril, Ramipril, Lisinopril, Perindopril and ARB: Losartan, Valsartan, Candesartan, Telmisartan.

\section{Objectives:}

1. To explore an informational material (scientific publications, guidelines for physicians, tutorials) about modern methods of treatment of patients with arterial hypertension.

2. To determine indicators of clinical efficacy of drug therapy of hypertension and types of cost, their use in comparative pharmacoeconomic study is most appropriate.

3. To calculate the costs for pharmacotherapy of ACEls - Fosinopril, Ramipril, Lisinopril, Perindopril, ARB - Losartan, Valsartan, Candesartan, Telmisartan)

4. To conduct a pharmacoeconomic cost-effectiveness analysis and the budget impact analysis of the use of ACEls drugs - Fosinopril, Ramipril, Lisinopril, Perindopril, ARB - Losartan, Valsartan, Candesartan, Telmisartan in the treatment of hypertension and to determine the optimal position of pharmacoeconomics of medical technology in the treatment of hypertension

\section{Pecularities of the study}

In the first phase, to identify differences between the drugs ACEI and ARBS $\mathrm{II}$, an analysis was conducted of various information sources: pharmacoeconomic and clinical research in foreign databases (DB) - in Pubmed, Medlink, etc. keyword: "angiotensin converting enzyme inhibitors, blockers of receptors of angiotensin-II, renin-angiotensin-aldosterone system, fosinopril, ramipril", "lisinopril", "perindopril", "valsartan", "Iosartan", "telmisartan", "candesartan", "cardiovascular diseases", "pharmacoeconomics", "cost analysis", "costeffectiveness "analysis", "budget impact", "stroke", "myocardial infarction", "arterial hypertension". Also, the information search was conducted in the Russian-language databases, Russian medicine, Central scientific medical library of the First MGMU named after I. M. Sechenov, scientific electronic library elibrary. ru, CyberLink and free search engine such as Yandex, Google etc. Information search in Russian database included the following keywords: ACEIs, ARB, RAAS, fosinopril, ramipril, lisinopril, perindopril, valsartan, losartan, telmisartan, candesartan, hypertension, myocardial infarction, stroke, cardiovascular diseases , analysis of the "impact on budget", the cost-minimization analysis, cost analysis, pharmacoeconomics. In the search process, corresponding to the inquiry, it was found 113 publications. Next, duplicate publications and studies not related to the problem of treatment of hypertension with use of antihypertensive drugs were excluded; and was not included in further analysis of randomized clinical trials (RCTS) to compare drugs were evaluated in combination with other antihypertensive agents. The level of evidence was determined according to the scales assessing the levels of evidence results RCTS of drugs and the assessment of levels of credibility of evidence RCT LS. In the first place was out of the study with level of evidence A or b: the evidence summarized in the systematic review, meta-analysis, and evidence obtained in prospective RCTS, respectively. In the absence of such research was considered with a lower level of evidence. The results are summarized in a special table for analysis and subjected to peer review. Thus, after screening for detailed analysis included 22 publications (tab. 1). 
Table 1. Results of information retrieval

\begin{tabular}{|c|c|c|c|c|c|c|c|}
\hline \multicolumn{8}{|c|}{ Fosinopril } \\
\hline Name of the study & Authors & Year & Country & $\begin{array}{l}\text { Objects of study } \\
\text { (medicines) }\end{array}$ & Design of study & $\begin{array}{l}\text { Number of } \\
\text { patients }\end{array}$ & $\begin{array}{c}\text { Time } \\
\text { horizon }\end{array}$ \\
\hline $\begin{array}{l}\text { Treatment of Senile Hypertension } \\
\text { Treatment of Senile Hypertension The Fosinopril in } \\
\text { Old Patients Study (FOPS) }\end{array}$ & Vetter W & 1997 & Switzerland & fosinopril & Open-label study & 757 & 12 weeks \\
\hline $\begin{array}{l}\text { Study of the efficacy and safety of fosinopril in } \\
\text { general practice in 19,435 hypertensive patients } \\
\text { (FLIGHT Study) }\end{array}$ & $\begin{array}{l}\text { Berdah J1, Guest } \\
\text { M, Salvador M. }\end{array}$ & 1998 & France & fosinopril & $\begin{array}{l}\text { randomized, } \\
\text { blind, multicenter }\end{array}$ & 19432 & 12 weeks \\
\hline $\begin{array}{l}\text { Outcome results of the Fosinopril Versus Am- } \\
\text { Iodipine Cardiovascular Events Randomized Trial } \\
\text { (FACET) in patients with hypertension and NIDDM }\end{array}$ & $\begin{array}{l}\text { Tatti P1, Pahor } \\
\text { M, Byington RP, Di } \\
\text { Mauro et al. }\end{array}$ & 1998 & Italy & $\begin{array}{l}\text { 1)fosinopril } \\
\text { 2)amlodipin }\end{array}$ & randomized & 380 & 3,5 years \\
\hline \multicolumn{8}{|c|}{ Ramipril } \\
\hline Name of the study & Authors & Year & Country & $\begin{array}{l}\text { Objects of study } \\
\text { (medicines) }\end{array}$ & Design of study & $\begin{array}{l}\text { Number of } \\
\text { patients }\end{array}$ & $\begin{array}{c}\text { Time } \\
\text { horizon }\end{array}$ \\
\hline $\begin{array}{l}\text { The CARE Study: a postmarket- } \\
\text { ing evaluation of ramipril in } 11,100 \text { patients. } \\
\text { The Clinical Altace Real-WorldEfficacy (CARE) } \\
\text { Investigators }\end{array}$ & Kaplan NM & 1996 & USA & ramipril & $\begin{array}{l}\text { Open-label, } \\
\text { multicenter }\end{array}$ & 8261 & 2 months \\
\hline $\begin{array}{l}\text { Long-term effects of rami- } \\
\text { pril on cardiovascular events and } \\
\text { on diabetes: results of the HOPE study extension }\end{array}$ & $\begin{array}{l}\text { Bosch J1, Lonn } \\
\text { E, Pogue J, Arnold } \\
\text { JM, Dagenais } \\
\text { GR, Yusuf S }\end{array}$ & 2005 & Canada & ramipril & $\begin{array}{l}\text { randomized, } \\
\text { double-blind, } \\
\text { multicenter }\end{array}$ & 4528 & 4,5 years \\
\hline \multicolumn{8}{|c|}{ Lisinopril } \\
\hline Name of the study & Authors & Year & Country & $\begin{array}{l}\text { Objects of study } \\
\text { (medicines) }\end{array}$ & Design of study & $\begin{array}{l}\text { Number of } \\
\text { patients }\end{array}$ & $\begin{array}{c}\text { Time } \\
\text { horizon }\end{array}$ \\
\hline $\begin{array}{l}\text { Comparison of valsartan } 160 \mathrm{mg} \text { with lisinopril } \\
20 \mathrm{mg} \text {, given as monotherapy or in combination } \\
\text { with a diuretic, for the treatment of hypertension: } \\
\text { the Blood Pressure Reduction and Tolerability } \\
\text { of Valsartan in Comparison with Lisinopril } \\
\text { (PREVAIL) study }\end{array}$ & $\begin{array}{l}\text { Malacco E1, San- } \\
\text { tonastaso M, Varì } \\
\text { NA et al. }\end{array}$ & 2004 & Italy & $\begin{array}{l}\text { 1)valsartan } \\
\text { 2)lisinopril }\end{array}$ & $\begin{array}{l}\text { randomized, } \\
\text { double-blind }\end{array}$ & 1213 & 16 weeks \\
\hline $\begin{array}{c}\text { The Antihypertensive and Lipid Lowering } \\
\text { Treatment to Prevent Heart Attack Trial (ALLHAT) } \\
\text { Heart Failure Validation Study: diagnosis and } \\
\text { prognosis }\end{array}$ & $\begin{array}{l}\text { Einhorn PT1, Davis } \\
\text { BR, Massie BM } \\
\text { et al. }\end{array}$ & 2007 & USA & $\begin{array}{l}\text { 1) chlortalidon, } \\
\text { 2)amldipin, } \\
\text { 3)lisinopril } \\
\text { 4) doxazosin } \\
\end{array}$ & $\begin{array}{l}\text { randomized, } \\
\text { double-blind, } \\
\text { multicenter }\end{array}$ & 42,418 & 5 years \\
\hline $\begin{array}{l}\text { Nocturnal reduction of blood pressure and } \\
\text { the antihypertensive response to a diuretic or } \\
\text { angiotensin converting enzyme inhibitor in obese } \\
\text { hypertensive patients. TROPHY Study Group. }\end{array}$ & $\begin{array}{l}\text { Weir MR1, Reisin } \\
\text { E, Falkner B et al. }\end{array}$ & 1998 & USA & $\begin{array}{l}\text { 1)lisinopril } \\
\text { 2)hydrochlorti- } \\
\text { azide }\end{array}$ & $\begin{array}{l}\text { randomized, } \\
\text { multicenter }\end{array}$ & 124 & 12 weeks \\
\hline \multicolumn{8}{|c|}{ Perindopril } \\
\hline Name of the study & Authors & Year & Country & $\begin{array}{l}\text { Objects of study } \\
\text { (medicines) }\end{array}$ & Design of study & $\begin{array}{l}\text { Number of } \\
\text { patients }\end{array}$ & $\begin{array}{c}\text { Time } \\
\text { horizon }\end{array}$ \\
\hline $\begin{array}{l}\text { Efficacy of perindopril in reduction of cardiovas- } \\
\text { cular events among patients with stable coronary } \\
\text { artery disease: randomised, double-blind, } \\
\text { placebo-controlled, multicentre trial (the EUROPA } \\
\text { study) }\end{array}$ & Fox KM & 2003 & England & $\begin{array}{l}\text { 1)perindopril } \\
\text { 2)placebo }\end{array}$ & $\begin{array}{l}\text { randomized, } \\
\text { double-blind, } \\
\text { multicenter }\end{array}$ & 12218 & 4,2 years \\
\hline
\end{tabular}




\begin{tabular}{|c|c|c|c|c|c|c|c|}
\hline \multicolumn{8}{|c|}{ Losartan } \\
\hline Name of the study & Authors & Year & Country & $\begin{array}{l}\text { Objects of study } \\
\text { (medicines) }\end{array}$ & Design of study & $\begin{array}{c}\text { Number of } \\
\text { patients }\end{array}$ & $\begin{array}{c}\text { Time } \\
\text { horizon }\end{array}$ \\
\hline $\begin{array}{c}\text { Effects of losartan on renal and cardiovascular } \\
\text { outcomes in patients with type } 2 \text { diabetes and } \\
\text { nephropathy }\end{array}$ & $\begin{array}{l}\text { Brenner BM1, Coo- } \\
\text { per ME, de Zeeuw } \\
\text { D et al. }\end{array}$ & 2000 & USA & $\begin{array}{l}\text { 1)losartan } \\
\text { 2)placebo }\end{array}$ & $\begin{array}{l}\text { randomized, } \\
\text { double-blind, }\end{array}$ & 1513 & 3,5 years \\
\hline $\begin{array}{l}\text { Effects of losartan and captopril on mortal- } \\
\text { ity and morbidity in high-risk patients after } \\
\text { acute myocardial infarction: the OPTIMAAL } \\
\text { randomised trial. Optimal Trial in Myocardial } \\
\text { Infarction with Angiotensin II Antagonist Losartan }\end{array}$ & $\begin{array}{l}\text { Dickstein } \\
\mathrm{K} 1, \text { Kjekshus J }\end{array}$ & 2002 & Norway & $\begin{array}{l}\text { 1)losartan } \\
\text { 2)captopril }\end{array}$ & $\begin{array}{l}\text { randomized, } \\
\text { blind, multicenter }\end{array}$ & 5477 & 2,7 years \\
\hline $\begin{array}{c}\text { Сравнительная эффрективность оригинального } \\
\text { и генерического losartana у больных } \\
\text { артериальной гипертензией }\end{array}$ & $\begin{array}{l}\text { С.В. Недоуеаrs, Т.A. } \\
\text { Чаляби и др. }\end{array}$ & 2007 & Russia & losartan & $\begin{array}{l}\text { randomized, } \\
\text { blind, multicenter }\end{array}$ & 40 & 3 months \\
\hline \multicolumn{8}{|c|}{ Valsartan } \\
\hline Name of the study & Authors & Year & Country & $\begin{array}{l}\text { Objects of study } \\
\text { (medicines) }\end{array}$ & Design of study & $\begin{array}{c}\text { Number of } \\
\text { patients }\end{array}$ & $\begin{array}{c}\text { Time } \\
\text { horizon }\end{array}$ \\
\hline $\begin{array}{l}\text { The Valsartan Antihypertensive Long-Term Use } \\
\text { Evaluation (VALUE) trial: outcomes in patients } \\
\text { receiving monotherapy }\end{array}$ & $\begin{array}{l}\text { Julius S1, Weber } \\
\text { MA, Kjeldsen SE } \\
\text { et al. }\end{array}$ & 2006 & USA & $\begin{array}{l}\text { 1) valsartan } \\
\text { 2)amlodipin }\end{array}$ & $\begin{array}{l}\text { randomized, } \\
\text { double-blind, } \\
\text { multicenter }\end{array}$ & 15245 & 3,2 years \\
\hline $\begin{array}{l}\text { Comparison of valsartan } 160 \mathrm{mg} \text { with lisinopril } \\
20 \mathrm{mg} \text {, given as monotherapy or in combination } \\
\text { with a diuretic, for the treatment of hypertension: } \\
\text { the Blood Pressure Reduction and Tolerability } \\
\text { of Valsartan in Comparison with Lisinopril } \\
\text { (PREVAIL) study }\end{array}$ & $\begin{array}{l}\text { Malacco E1, San- } \\
\text { tonastaso M, Varì } \\
\text { NA, Gargiulo } \\
\text { A, Spagnuolo V } \\
\text { et al. }\end{array}$ & 2004 & Italy & $\begin{array}{l}\text { 1)valsartan } \\
\text { 2)lisinopril }\end{array}$ & $\begin{array}{l}\text { randomized, } \\
\text { double-blind }\end{array}$ & 1213 & 16 weeks \\
\hline $\begin{array}{l}\text { Valsartan, captopril, or both in myocardial infarc- } \\
\text { tion complicated by heart failure, left ventricular } \\
\text { dysfunction, or both }\end{array}$ & $\begin{array}{l}\text { Pfeffer MA, McMur- } \\
\text { ray JJ, Velazquez } \\
\text { EJ et al. }\end{array}$ & 2003 & USA & $\begin{array}{l}\text { 1)valsartan } \\
\text { 2)captopril }\end{array}$ & $\begin{array}{l}\text { randomized, } \\
\text { double-blind, } \\
\text { multicenter }\end{array}$ & 14703 & 2,7 years \\
\hline \multicolumn{8}{|c|}{ Telmisartan } \\
\hline Name of the study & Authors & Year & Country & $\begin{array}{l}\text { Objects of study } \\
\text { (medicines) }\end{array}$ & Design of study & $\begin{array}{c}\text { Number of } \\
\text { patients }\end{array}$ & $\begin{array}{c}\text { Time } \\
\text { horizon }\end{array}$ \\
\hline $\begin{array}{l}\text { Comparison of trough effect of telmisartan vs } \\
\text { perindopril using self blood pressure measure- } \\
\text { ment: EVERESTE study }\end{array}$ & $\begin{array}{l}\text { Ragot S1, Ezzaher } \\
\text { A et al. }\end{array}$ & 2002 & France & $\begin{array}{l}\text { 1)telmisartan } \\
\text { 2)perindopril }\end{array}$ & $\begin{array}{c}\text { randomized, } \\
\text { open-label }\end{array}$ & 441 & 12 weeks \\
\hline $\begin{array}{l}\text { Telmisartan to prevent recurrent stroke and } \\
\text { cardiovascular events. }\end{array}$ & $\begin{array}{l}\text { Yusuf S, Diener HC, } \\
\text { Sacco RL et al. }\end{array}$ & 2008 & Canada & telmisartan & $\begin{array}{l}\text { randomized, } \\
\text { double-blind, } \\
\text { multicenter }\end{array}$ & 20332 & 2,5 years \\
\hline $\begin{array}{l}\text { Telmisartan, ramipril, or both in patients at high } \\
\text { risk for vascular events }\end{array}$ & $\begin{array}{l}\text { Yusuf S, Teo } \\
\text { KK, Pogue J, Dyal } \\
\text { L et al. }\end{array}$ & 2008 & Canada & $\begin{array}{l}\text { 1)telmisartan } \\
\text { 2)ramipril }\end{array}$ & $\begin{array}{l}\text { randomized, } \\
\text { double-blind, } \\
\text { multicenter }\end{array}$ & 25620 & 4,6 years \\
\hline \multicolumn{8}{|c|}{ Candesartan } \\
\hline Name of the study & Authors & Year & Country & $\begin{array}{l}\text { Objects of study } \\
\text { (medicines) }\end{array}$ & Design of study & $\begin{array}{l}\text { Number of } \\
\text { patients }\end{array}$ & $\begin{array}{c}\text { Time } \\
\text { horizon }\end{array}$ \\
\hline $\begin{array}{l}\text { The Study on Cognition and Prognosis in the El- } \\
\text { derly (SCOPE): principal results of a randomized } \\
\text { double-blind intervention trial }\end{array}$ & $\begin{array}{l}\text { Lithell H1, Hansson } \\
\text { L, Skoog I et al. }\end{array}$ & 2003 & Sweden & $\begin{array}{l}\text { 1) candesartan } \\
\text { 2)placebo }\end{array}$ & $\begin{array}{l}\text { randomized, } \\
\text { double-blind, } \\
\text { multicenter }\end{array}$ & 4964 & 3,7 years \\
\hline $\begin{array}{l}\text { Comparative effects of candesartan } \\
\text { cilexetil and losartan in patients with } \\
\text { systemic hypertension. Candesartan Versus Losa } \\
\text { rtan Efficacy Comparison (CANDLE) Study Group }\end{array}$ & $\begin{array}{l}\text { Gradman AH1, Lew- } \\
\text { in A, Bowling } \\
\text { BT, Tonkon M et al. }\end{array}$ & 1999 & USA & $\begin{array}{l}\text { 1) candesartan } \\
\text { 2)losartan }\end{array}$ & $\begin{array}{l}\text { randomized, } \\
\text { double-blind, } \\
\text { multicenter }\end{array}$ & 332 & 8 weeks \\
\hline $\begin{array}{c}\text { Effects of candesartan compared with amlodipine } \\
\text { in hypertensive patients with high cardiovascu- } \\
\text { lar risks:candesartan antihypertensive survival } \\
\text { evaluation in Japan trial }\end{array}$ & $\begin{array}{l}\text { Ogihara T1, Nakao } \\
\text { K, Fukui T et al. }\end{array}$ & 2008 & Japan & $\begin{array}{l}\text { 1) candesartan } \\
\text { 2)amlodipin }\end{array}$ & $\begin{array}{l}\text { randomized, } \\
\text { open-label, } \\
\text { multicenter }\end{array}$ & 4728 & 3,2 years \\
\hline $\begin{array}{l}\text { Effects of candesartan in patients with chronic } \\
\text { heart failure and reduced left-ventricular systolic } \\
\text { function intolerant to angiotensin-converting-en- } \\
\text { zyme inhibitors: the CHARM-Alternative trial }\end{array}$ & $\begin{array}{l}\text { Granger CB1, Mc- } \\
\text { Murray JJ, Yusuf } \\
\text { S et al. }\end{array}$ & 2003 & USA & $\begin{array}{l}\text { 1) candesartan } \\
\text { 2)placebo }\end{array}$ & $\begin{array}{l}\text { randomized, } \\
\text { multicenter }\end{array}$ & 2028 & 2,8 years \\
\hline
\end{tabular}




\section{Effectiveness analysis}

For analysis of efficiency and analysis of "cost-effectiveness" on the basis of information found during the search of RCTS for each drug of the two groups of antihypertensive drugs - ACE-I (fosinopril, lisinopril, ramipril and perindopril) and ARBS II (losartan, valsartan, candesartan and telmisartan), we determined the criterion of effectiveness is the achievement of target blood pressure. In addition to the criterion of efficiency for analysis "cost-effectiveness" and cost analysis, we have identified unwanted cardiovascular events which included: THEY (fatal and nonfatal), stroke (fatal and nonfatal) and SN, as well as side effects of drug therapy such as hypotension, cough and angioedema. Data analysis of effectiveness are presented in table 2.

Table 3. Cost of drugs

\begin{tabular}{|c|c|c|c|}
\hline $\begin{array}{c}\text { Dosage form/ } \\
\text { number }\end{array}$ & Price, rub. & $\begin{array}{c}\text { Price of } 1 \mathrm{mg}, \\
\text { rub. }\end{array}$ & $\begin{array}{c}\text { Mean price of } 1 \mathrm{mg} \text {, } \\
\text { rub. }\end{array}$ \\
\hline \multicolumn{4}{|l|}{$\begin{array}{c}\text { Perindopril } \\
\text { (Prestarium A) }\end{array}$} \\
\hline tabl. 5 mg № 30 & 456,21 & 3,04 & \multirow{4}{*}{2,66} \\
\hline tabl. 5 mg № 90 & 1358,67 & 3,02 & \\
\hline tabl. 10 mg № 30 & 684,38 & 2,28 & \\
\hline tabl. 10 mg № 90 & 2076,53 & 2,31 & \\
\hline \multicolumn{4}{|l|}{ Ramipril (Tritace) } \\
\hline tabl. $2.5 \mathrm{mg}$ №28 & 809,60 & 11,57 & \multirow{3}{*}{7,22} \\
\hline tabl. 5mg №28 & 900,86 & 6,43 & \\
\hline tabl.10mg №28 & 1022,50 & 3,65 & \\
\hline \multicolumn{4}{|l|}{$\begin{array}{l}\text { Lisinopril } \\
\text { (Diroton) }\end{array}$} \\
\hline tabl. 2,5mg №14 & 60,00 & 1,71 & \multirow{11}{*}{1,15} \\
\hline tabl. 2,5mg №28 & 107,50 & 1,54 & \\
\hline tabl. 5mg №14 & 133,00 & 1,90 & \\
\hline tabl. $5 \mathrm{mg}$ №28 & 196,50 & 1,40 & \\
\hline tabl. 5mg №56 & 327,00 & 1,17 & \\
\hline tabl. 10mg №14 & 133,00 & 0,95 & \\
\hline tabl. 10mg №28 & 274,00 & 0,98 & \\
\hline tabl. 10mg №56 & 501,00 & 0,89 & \\
\hline tabl. 20mg №14 & 196,00 & 0,70 & \\
\hline tabl. 20mg №28 & 446,00 & 0,80 & \\
\hline tabl. 20mg №56 & 699,00 & 0,62 & \\
\hline
\end{tabular}

The performance indicator for each of the studied drugs of antihypertensive drugs groups ACEI (fosinopril, lisinopril, ramipril and perindopril) and ARBS II (losartan, valsartan, candesartan and telmisartan) was taken from pre-registration studies phase III. Data on the incidence of adverse cardiovascular events and side effects mainly from post-marketing studies phase IV [1-24, 38].

\section{Cost analysis}

In the present study were evaluated only direct medical costs of using medicines: perindopril, ramipril, lisinopril, losartan, valsartan, candesartan and telmisartan in comparison with the medicine fosinopril. Prices on medicines were taken from the Internet resources www.medlux.ru and www.pharmindex.ru with further calculation of the average cost of $1 \mathrm{mg}$ of active substance (tab. 3).

\begin{tabular}{|c|c|c|c|}
\hline $\begin{array}{c}\text { Dosage form/ } \\
\text { number }\end{array}$ & Price, rub. & $\begin{array}{c}\text { Price of } 1 \mathrm{mg} \text {, } \\
\text { rub. }\end{array}$ & $\begin{array}{l}\text { Mean price of } 1 \mathrm{mg} \text {, } \\
\text { rub. }\end{array}$ \\
\hline \multicolumn{4}{|l|}{$\begin{array}{l}\text { Fosinopril } \\
\text { (Monopril) }\end{array}$} \\
\hline tabl. 20mg №28 & 410,00 & 0,73 & 0,73 \\
\hline \multicolumn{4}{|l|}{$\begin{array}{l}\text { Candesartan } \\
\text { (Atacand) }\end{array}$} \\
\hline tabl. 8mg №28 & 1598,47 & 7,14 & \multirow{3}{*}{4,75} \\
\hline tabl.16mg №28 & 1935,81 & 4,32 & \\
\hline tabl.32mg №28 & 2503,67 & 2,79 & \\
\hline \multicolumn{4}{|l|}{ Valsartan (Diovan) } \\
\hline $\begin{array}{l}\text { tabl. Coated } 80 \mathrm{mg} \\
\text { №28 }\end{array}$ & 1686,64 & 0,75 & \multirow{2}{*}{0,61} \\
\hline $\begin{array}{l}\text { tabl. Coated } \\
\text { 160mg №28 }\end{array}$ & 2071,56 & 0,46 & \\
\hline \multicolumn{4}{|l|}{$\begin{array}{l}\text { Telmisartan } \\
\text { (Micardis) }\end{array}$} \\
\hline tabl. 40mg №14 & 604,48 & 1,08 & \multirow{2}{*}{0,78} \\
\hline tabl. 80mg №28 & 1086,64 & 0,49 & \\
\hline \multicolumn{4}{|l|}{ Losartan (Cozaar) } \\
\hline $\begin{array}{l}\text { tabl. coated } 50 \mathrm{mg} \\
\text { №14 }\end{array}$ & 334,74 & 0,48 & \multirow{2}{*}{0,38} \\
\hline $\begin{array}{l}\text { tabl. coated } \\
\text { 100mg №28 }\end{array}$ & 772,62 & 0,28 & \\
\hline
\end{tabular}

According to the data presented in table 3 - least cost of $1 \mathrm{mg}$ for studied drugs: losartan - 0,38 rub., valsartan - 0,61 RUB.. and fosinopril - 0,73 RUB. The greatest value of $1 \mathrm{mg}$ was observed in LP: ramipril - 7,22 RUB., candesartan $-4,75$ RUB. and perindopril $-2,66$ RUB.

Table 2. Results of effectiveness analysis

\begin{tabular}{|c|c|c|c|c|c|c|c|}
\hline INN & $\begin{array}{c}\text { Achievement of } \\
\text { target AH \% }\end{array}$ & $\begin{array}{c}\text { Fatal /non-fatal } \\
\text { infarction \% }\end{array}$ & Heart failure \% & $\begin{array}{c}\text { Stroke (fatal and } \\
\text { non-fatal) \% }\end{array}$ & Hypotension \% & Cough \% & Angioedema, \% \\
\hline Losartan & $67,1^{[14]}$ & $6,66^{[12]}$ & $11,85^{[12]}$ & $6,39^{[12]}$ & $1,7^{[13]}$ & $1^{[13]}$ & $0,4^{[13]}$ \\
\hline Valsartan & $82,7^{[17]}$ & $4,82^{[15]}$ & $4,63^{[15]}$ & $4,21^{[15]}$ & $15,1^{[16]}$ & $1,7^{[16]}$ & $0,2^{[16]}$ \\
\hline Candesartan & $64^{[18]}$ & $2,83^{[19]}$ & $0,8^{[20]}$ & $3,59^{[19]}$ & $3,7^{[21]}$ & $0,2^{[21]}$ & $0,1^{[21]}$ \\
\hline Telmisartan & $58^{[2]}$ & $1,66^{[22]}$ & $1,9^{[22]}$ & $8,67^{[22]}$ & $3,9^{[22]}$ & $1,1^{[23]}$ & $0,2^{[22]}$ \\
\hline Perinopril & $46^{[2]}$ & $4,83^{[1]}$ & $0,7^{[1]}$ & $1,6^{[1]}$ & $1^{[1]}$ & $2,65^{[1]}$ & $\mathrm{N} / \mathrm{A}$ \\
\hline Ramipril & $85^{[4]}$ & $9,88^{[3]}$ & $9^{[3]}$ & $3,36^{[3]}$ & $1,89^{[3]}$ & $7,32^{[3]}$ & $\mathrm{N} / \mathrm{A}$ \\
\hline Lisinopril & $60^{[6]}$ & $2,2^{[5]}$ & $1,1^{[5]}$ & $1,6^{[5]}$ & $0,5^{[7]}$ & $7,2^{[7]}$ & $\mathrm{N} / \mathrm{A}$ \\
\hline Fosinopril & $79,8^{[9]}$ & $1,8^{[10]}$ & $0,2^{[11]}$ & $0,7^{[10]}$ & $0,6^{[11]}$ & $5^{[10]}$ & $\mathrm{N} / \mathrm{A}$ \\
\hline
\end{tabular}

The table below shows that the highest percentage of achievement of BP has been demonstrated in drugs: ramipril $-85 \%$, valsartan $-82,7 \%$ and fosinopril - 79.8 per cent. The lowest incidence of mi was drugs: telmisartan and $1.66 \%$, fosinopril $-1.8 \%$ and lisinopril was $2.2 \%$. The lowest incidence of $\mathrm{CH}$ was drugs: fosinopril $-0,2 \%$, perindopril $-0.7 \%$ and candesartan and $0.8 \%$. The lowest frequency of stroke was drugs: fosinopril $-0,6 \%$, lisinopril $-1.3 \%$ of perindopril and by $1.6 \%$. The lowest frequency of hypotension was for drugs: lisinopril $-0,5 \%$, fosinopril $-0.6 \%$ and perindopril $-1 \%$. The lowest incidence of cough was drug: candesartan and $0.2 \%$, losartan $-1 \%$ and telmisartan $-1,1 \%$. The incidence of angioneurotic edema was evaluated only for drugs of group II ARBS (losartan, valsartan, candesartan and telmisartan), drug from the group of ACE inhibitors (perindopril, ramipril, lisinopril, and fosinopril) of such data in RCTS has been presented. 
Taking into account the results of information retrieval and recommendation of application guidelines, budget and planning of the health system in the treatment of hypertension, for further calculations we took the time interval in the amount of one years.

All calculations of the value of pharmacotherapy in the treatment of various conditions was based on the standards from table 4 .

Table 4. The standards used in the calculation of direct costs

\begin{tabular}{|c|c|}
\hline Nosology & Name of standard \\
\hline \multirow{2}{*}{$\begin{array}{l}\text { Arterial } \\
\text { hypertension } \\
\text { (AH) }\end{array}$} & $\begin{array}{l}\text { The standard of emergency medical care in diseases } \\
\text { characterised by high blood pressure (Ministry of health } \\
\text { Order No. } 1513 \text { n of December } 24,2012 \text { ) }\end{array}$ \\
\hline & $\begin{array}{c}\text { The standard of primary health care in primary arterial } \\
\text { hypertension (Hypertensive disease) (Ministry of health } \\
\text { Order No. } 708 \text { n from November 9, 2012) }\end{array}$ \\
\hline \multirow{2}{*}{$\begin{array}{l}\text { Miocardial } \\
\text { infarction (MI) }\end{array}$} & $\begin{array}{l}\text { The standard ambulance in acute coronary syndrome with } \\
\text { ST segment elevation (Ministry of health Order No. 1383n of } \\
\text { December 24, 2012) }\end{array}$ \\
\hline & $\begin{array}{l}\text { About approval of the standard of specialized medical care in } \\
\text { acute myocardial infarction with ST-segment elevation of the } \\
\text { electrocardiogram (Order of MH of the Russian Federation } \\
\text { No. } 839 \text { of } 24 \text { May 2011) }\end{array}$ \\
\hline \multirow{2}{*}{ Stroke } & $\begin{array}{l}\text { The standard of emergency medical care in stroke (Ministry } \\
\text { of health Order No. 1282n of } 20 \text { December 2012) }\end{array}$ \\
\hline & $\begin{array}{l}\text { The standard of specialized medical care in myocardial injury } \\
\text { (Ministry of health Order No. 1740n of December 29, 2012) }\end{array}$ \\
\hline \multirow{2}{*}{$\begin{array}{l}\text { Cardiac } \\
\text { insufficiency } \\
\text { (CI) }\end{array}$} & $\begin{array}{l}\text { The standard of emergency medical care in heart failure } \\
\text { (Ministry of health Order No. 1283n of } 20 \text { December 2012) }\end{array}$ \\
\hline & $\begin{array}{l}\text { The standard of specialized medical care in heart failure } \\
\text { (Ministry of health Order No. 1554n of } 24 \text { December 2012) }\end{array}$ \\
\hline $\begin{array}{l}\text { Angioneurotic } \\
\text { edema }\end{array}$ & $\begin{array}{l}\text { The standard ambulance in angioneurotic edema, hives } \\
\text { (Ministry of health Order No. 1430n of } 24 \text { December 2012) }\end{array}$ \\
\hline
\end{tabular}

Feature of the present cost analysis was that in addition to the basic calculation of the cost of pharmacotherapy, we also calculated the compensation cost for the treatment of cardiovascular events and adverse effects from each specific PL.

Thus, the cost of providing out-patient or emergency medical care for hypertension at each stage was 9501 rub. and $\mathbf{5} 228$ rub. respectively; during myocardial infarction at each stage - 375255 rub. и 17421 rub. respectively; during cardiac insufficiency - 67757 rub. and 9526 rub. respectively; during stroke - 289715 rub. and 20072 rub. respectively; during angioneurotic edema - 27010 rub. The results of the cost analysis are presented in table 5 .

\section{Cost-effectiveness analysis}

The calculations of cost-effectiveness analysis were performed separately for each drug. The result of the analysis is represented as a cost per unit of effectiveness with the subsequent comparison of the obtained results. Calculation in accordance with the methodology, was carried out according to the formula:

\section{$\mathrm{CER}=(\mathrm{DC}+\mathrm{IC}) / \mathrm{Ef}$, where}

CER - cost-effectiveness ratio (defines costs, which are necessary for a unit of effectiveness, for example per 1 treated patient);

- DC - direct costs, including direct medical and direct non-medical costs;;

- IC - indirect costs;

- Ef - effectiveness (relative amount of treated patients).

After evaluating the cost and effectiveness of pharmacotherapy for $\mathrm{AH}$ with antihypertensive drugs values of the cost-effectiveness ratios (CER) as the ratio of total cost to percentage of patients achieved target arterial pressure level were calculated. (табл. 6).

Table 6. Cost-effectiveness ratio based on destination of target arterial pressure level

\begin{tabular}{|c|c|c|c|}
\hline INN & $\begin{array}{c}\text { Destination of } \\
\text { target level of } \\
\text { AP, } \%\end{array}$ & $\begin{array}{c}\text { Total costs, } \\
\text { rub. }\end{array}$ & $\begin{array}{c}\text { Cost-effectiveness } \\
\text { ratio, rub. }\end{array}$ \\
\hline Perindopril & 46 & 37808 & 822 \\
\hline Ramipril & 85 & 69591 & 819 \\
\hline Lisinopril & 60 & 27800 & 463 \\
\hline Fosinopril & 79,8 & 22719 & 285 \\
\hline Losartan & 67,1 & 68576 & 1022 \\
\hline Valsartan & 82,7 & 49075 & 593 \\
\hline Candesartan & 64 & 36278 & 567 \\
\hline Telmisartan & 58 & 47762 & 823 \\
\hline
\end{tabular}

During cost-effectiveness analysis is defined that Fosinopril has the lowest CER. From table 6 it is seen that the smallest lowest CER.have the following LP: fosinopril -285 , lisinopril -463 and candesartan -567 .

\section{Budget impact analysis}

The next step was the implementation of budget impact analysis based on the data about the duration of treatment of patients suffering from $\mathrm{AH}$, to assess the economic impact on the health care budget when choosing therapy. As part of this analysis by time horizon compared to the use of alternatives 365 days in accordance with the recommended instructions for use was analyzed.

Table 5. Structure of direct costs

\begin{tabular}{|c|c|c|c|c|c|c|}
\hline \multirow[b]{2}{*}{ INN } & \multicolumn{4}{|c|}{ Costs: } & \multirow{2}{*}{$\begin{array}{l}\text { Compensation of side } \\
\text { effects, rub. }\end{array}$} & \multirow{2}{*}{ Total costs, rub. } \\
\hline & AH, rub. & Cl, rub. & Stroke, rub. & Cl, rub. & & \\
\hline Perindopril & 13328 & 538 & 4949 & 18960 & 19 & 37795 \\
\hline Ramipril & 13374 & 6916 & 10409 & 38794 & 50 & 69543 \\
\hline Lisinopril & 13306 & 844 & 4957 & 8635 & 44 & 27786 \\
\hline Fosinopril & 13329 & 154 & 2169 & 7068 & 32 & 22751 \\
\hline Losartan & 13349 & 9084 & 19753 & 26150 & 121 & 68458 \\
\hline Valsartan & 13423 & 3558 & 13013 & 18922 & 125 & 49042 \\
\hline Candesartan & 13397 & 613 & 11099 & 11112 & 43 & 36264 \\
\hline Telmisartan & 13380 & 915 & 26859 & 6518 & 76 & 47747 \\
\hline
\end{tabular}

INN- international nonproprietary name, AH-arterial hypertension, $\mathrm{Cl}$-cardiac insufficiency, IM - myocardial infarction, SE - side effects

From the above table it is seem that the lowest total costs have the following drugs: fosinopril -22751 rub., lisinopril -27786 rub. and candesartan 36264 rub. 
The calculation of costs was conducted using formula:

$$
\mathrm{BIA}=\text { Cost }_{1}-\text { - }_{\text {ost }} \text {, }
$$

где Cost $_{1}$ - total costs of the first type of treatment (rubles);

Cost $_{2}-$ - total costs of the second type of treatment (rubles);

BIA (Budget Impact Analysis) - budget impact analysis (rubles).

Figure 1 shows the total cost of treatment of 1 patient with hypertension with different antihypertensive drugs in the treatment of hypertension.

\section{Conclusions:}

During direct costs analysis for AH therapy on the basis of current standards of rendering medical care for $\mathrm{AH}$ patients the total costs for two types of antihypertensive drugs were performed: fosinopril - 22751 rub. compared with other drugs: perindopril - 37 795rub., ramipril - 69 543rub., lisinopril 27 786rub., losartan - 68 458rub., valsartan - 49 042rub., candertan - 36264 rub., telmisartan- 47 747rub.

Basing on the cost-effectiveness analysis it is showed that Fosinopril

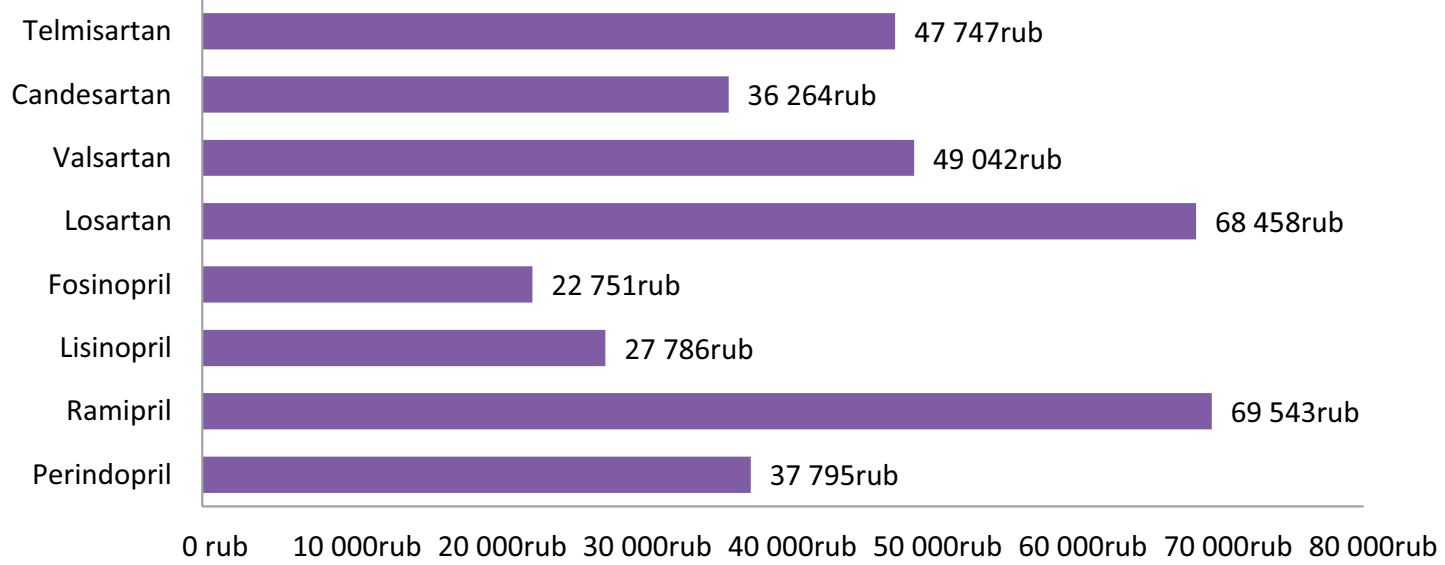

Figure 1. Total costs for each medicine

Figure 1 shows that drug fosinopril has the least total costs, therefore, the drug fosinopril comparison with the other drugs for the demonstration of economy of budgetary funds.

Next, we calculated of the transitions from different drugs to fosinopril as the drug with the lowest total cost has pharmacoeconomic advantage 285 rub. in therapy of $\mathrm{AH}$, as this type of treatment requires the least costs for 1 case of determination of target level of arterial pressure compared with drugs: Perindopril - 822 rub., Ramipril 819 rub., Lisinopril - 463 rub., Losartan - 1021 rub., Valsartan - 593 rub., Candesartan - 567 rub., Telmisartan - 823 rub.

Budget impact analysis showed that usage of Fosinopril in AH treatment

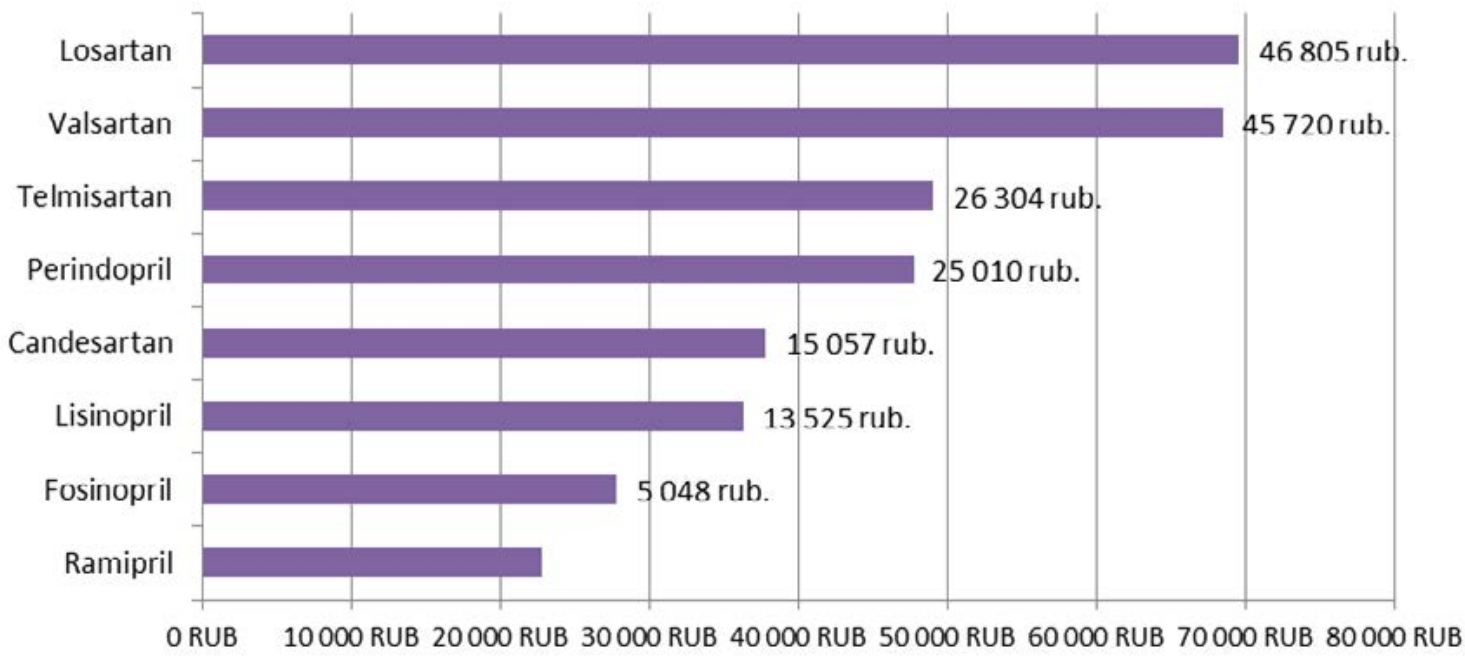

Figure 2. Monetary economy during transfer to fosinopril

The results obtained demonstrate fiscal savings when transferring all patients to other LP on treatment with fosinopril. With this transfer, the cost savings will be from 5048 rub. to 46805 rub. a year, depending on the drug. (fig.2).

\section{Sensitivity analysis}

For identification of the fact will be the usage of fosinopril still cost-effective under another profile of costs, the one-factor sensitivity analysis is conducted. As variables values of the main drugs of pharmacotherapy were considered. Sensitivity analysis defines, how the change in the value of two classes of antihypertensive drugs ACEls and ARB will affect the cost - effectiveness ratios compared with drugs: Perindopril, Ramipril, Lisinopril, Losartan, Valsartan, Candesartan and Telmisartan allows to save from 5048 rubles to 46805 rubles per 1 patient per year.

\section{References}

1. Fox K.M.; EURopean trial On reduction of cardiac events with Perindopril in stable coronary Artery disease Investigators. Efficacy of perindopril in reduction of cardiovascular events among patients with stable coronary artery disease: ran_domised, double_blind, placebo_controlled, multicentre 
trial (the EUROPA study) // Lancet. 2003. V. 362. P. 782-788.

2. Ragot S, Ezzaher A, Meunier A, Poterre M, Bourkaib R, Herpin D. Comparison of trough effect of telmisartan vs perindopril using self blood pressure measurement: EVERESTE study. J Hum Hypertens 2002; 16(12): 865-873.

3. Effects of ramipril on cardiovascular and microvascular outcomes in people with diabetes mellitus: results of the HOPE study and MICRO\$HOPE substudy. Heart Outcomes Prevention Evaluation Study Investigators. Lancet. 2000. - 355(9200). - 253-259.

4. Kaplan N.M. The CARE Study: a postmarketing evaluation of ramipril in 11,100 patients. The Clinical Altace Real-World Efficacy (CARE) Investigators. Clin Ther 1996; 18(4): 658-670.

5. Davis B.R., Cutler J.A., Gordon D.J. et al. Rationale and design for the Antihypertensive and Lipid Lowering Treatment to Prevent Heart Attack Trial (ALLHAT). ALLHAT Research Group. Am J Hypertens 1996;9(4 Pt 1):342-60.

6. Weir M.R., Reisin E., Falkner B. et al. Nocturnal reduction of blood pressure and the antihypertensive response to a diuretic or angiotensin converting enzyme inhibitor in obese hypertensive patients. TROPHY Study Group. Am J Hypertens 1998;11 (8 Pt 1):914-20.

7. Malacco E., Santonastaso M., Vari N.A. et al. Comparison of valsartan 160 $\mathrm{mg}$ with lisinopril $20 \mathrm{mg}$, given as monotherapy or in combination with a diuretic, for the treatment of hypertension: the Blood Pressure Reduction and Tolerability of Valsartan in Comparison with Lisinopril (PREVAIL) study. Clin Ther 2004;26(6):855-65.

8. Vetter W. Treatment of senile hypertension: the Fosinopril in Old Patients Study (FOPS) // AJH. 1997. Vol. 10. S. 255-261.

9. Berdah J., Guest M., Salvador M. Study of the efficacy and safety of fosinopril in general practice in 19,435 hypertensive patients (FLIGHT Study) // Ann. Cardiol. Angiol. 1998. Vol. 47(3). P. 169-175.

10. Tatti P., Pahor M., Byington R.P. et al. Outcome results of the fosinipri vs amlodipine cardiovascular events randomized trial (FACET) in patients with hypertension and NIDDM // Diabetes Care. 1998. Vol. 21. P. 597-603.

11. Diercks GF; Janssen WM; van Boven AJ; Rationale, design, and baseline characteristics of a trial of prevention of cardiovascular and renal disease with fosinopril and pravastatin in nonhypertensive, nonhypercholesterolemic subjects with microalbuminuria (the Prevention of REnal and Vascular ENdstage Disease Intervention Trial [PREVEND IT]). Am J Cardiol, 2000 Sep. 15, 86 (6): 635-8.

12. Brenner BM, Cooper ME, de Zeeuw D, Grunfeld J-P, Keane WF, Kurokawa K, McGill JB, Mitch WE, Parving HH, Remuzzi G, Ribeiro AB, Schluchter MD, Snavely D, Zhang Z, Simpson R, Ramjit D, Shahinfar S: Reduction of Endpoints in NIDDM with the Angiotensin II Antagonist Losartan (RENAAL). JRAAS 2000;1:328-35

13. Dickstein, K. Effects of losartan and captopril on mortality and morbidity in high-risk patients after acute myocardial infarction: the OPTIMAAL randomised trial. Optimal Trial in Myocardial Infarction with Angiotensin II Antagonist Losartan / K. Dickstein, J. Kjekshus // Lancet. - 2002. - Vol. 360, N 9335. - P. 752-760.

14. Nedogoda S. V., MTAC, V. V., Chalabi T. A., Brel, W. A., Mazin G. V. Comparative efficacy and originlnaya generic losartan in patients with essential hypertension // cardiovascular therapy and prevention, 2007, №. 6, pp. 10-14

15. Kjeldsen SE, Julius S, Mancia G et al. Effects of valsartan compared to amlodipine on preventing type 2 diabetes in high-risk hypertensive patients: the VALUE trial. J Hypertens 2006; 24: 1405-12.

16. Pfeffer MA, McMurray JJ, Velazquez EJ, Rouleau JL, Kwber L, Maggioni AP, Solomon SD, Swedberg K, Van de Werf F, White H, Leimberger JD, Henis M, Edwards S, Zelenkofske S, Sellers MA, Califf RM. Valsartan, captopril, or both in myocardial infarction complicated by heart failure, left ventricular dysfunction, or both.. N Engl J Med 2003;349:1893-906

17. Malacco E., Santonastaso M., Vari N.A. et al. Comparison of valsartan 160 $\mathrm{mg}$ with lisinopril $20 \mathrm{mg}$, given as monotherapy or in combination with a diuretic, for the treatment of hypertension: the Blood Pressure Reduction and Tolerability of Valsartan in Comparison with Lisinopril (PREVAIL) study. Clin Ther 2004;26(6):855-65.

18. Gradman AH, Lewin A, Bowling BT et al. Comparative effects of candesartan cilexetil and losartan in patients with systemic hypertension. Candesartan versus Losartan Efficacy Comparison (CANDLE) Study Group. Heart Dis 1999; $1: 52-7$

19. Lithell H, Hansson L, Skoog I et al. SCOPE Study Group. The Study on
Cognition and Prognosis in the Elderly (SCOPE). Principal results of a randomised double-blind intervention trial. J Hypertens 2003; 21: 875 86.

20. Ogihara T, Nakao K, Fukui T, Fukiyama K, Ueshima K, Oba K, Sato T, Saruta $\mathrm{T}$. Effects of candesartan compared with amlodipine in hypertensive patients with high cardiovascular risks: candesartan antihypertensive survival evaluation in Japan trial.. Hypertension 2008 Feb;51:393-8

21. Granger CB, McMurray JJ, Yusuf $S$ et al. Effects of candesartan in patients with chronic heart failure and reduced left-ventricular systolic function intolerant to angiotensin-converting-enzyme inhibitors: the CHARMAlternative trial. Lancet 2003; 362 (9386): 772-6.

22. Yusuf S, Diener HC, Sacco RL, Cotton D, Ounpuu S, Lawton WA, Palesch Y, Martin RH, Albers GW, Bath P, Bornstein N, Chan BP, Chen ST, Cunha L, Dahluf B, De Keyser J, Donnan GA, Estol C, Gorelick P, Gu V, Hermansson K, Hilbrich L, Kaste M, Lu C, Machnig T. Telmisartan to Prevent Recurrent Stroke and Cardiovascular Events. N Engl J Med 2008;359:1225-37

23. Yusuf S, Teo KK, Pogue J, Dyal L, Copland I, Schumacher H, Dagenais G, Sleight $\mathrm{P}$, Anderson $\mathrm{C}$. Telmisartan, ramipril, or both in patients at high risk for vascular events.. N Engl J Med 2008;358:1547-59

24. Ragot S, Ezzaher A, Meunier A, Poterre M, Bourkaib R, Herpin D. Comparison of trough effect of telmisartan vs perindopril using self blood pressure measurement: EVERESTE study. J Hum Hypertens 2002; 16(12): 865-873.

25. Yagudina R.I., Babiy V.V. Methodological basics of effectiveness analysis of health technologies in pharmacoeconomic studies // Pharmacoeconomics: theory and practice. - 2015. - Vol.3, №1 - P.12-16

26. Yagudina R.I., Serpik V.G., Sorokovikov I.V. Methodological basics of analysis of "cost-effectiveness" // Pharmacoeconomics: theory and practice. - 2014. - Vol.2, №2. - P.28-31

27. Yagudina R.I., Sorokovikov I.V. PHARMACOECONOMICS OF TUBERCULOSIS: THE METHODOLOGICAL ASPECTS OF STUDIES // Pharmacoeconomics: theory and practice. - 2014. - Vol.2, №4 - P.14-17

28. Yagudina R.I., Serpik V.G. On the possibilities of combining budget impact analysis and cost-effectiveness analysis - development of «3D» pharmacoeconomic model // Pharmacoeconomics: theory and practice. - 2014. - Vol.2, №3. - P.9-13

29. Kulikov A.Yu., Litvinenko M.M. Methodological basics of modeling in the pharmacoeconomic studies: different levels of complexity and different value of the results obtained // Pharmacoeconomics: theory and practice. - 2014. - Vol.2, №2. - P.16-22

30. Yagudina R.I., Serpik V.G., Kulikov A.Yu. Pharmacoeconomics for the Health Care Managers: decisionmaking algorithm based on pharmacoeconomic assessments // Pharmacoeconomics: theory and practice. - 2014. - Vol.2, №1. - P.13-20

31. Diagnosis and treatment of arterial hypertension: Russian recommendations (fourth revision) // Systemic hypertension. 2010. No. 3. P. $5-26$

32. Karpov Yu. a. Treatment of patients with cardiovascular diseases: the role of ReninAngiotensin system blockade with using the Sartana // RMJ. 2009. No. 23. P. $1548-1554$.

33. Clinical pharmacology / ed. by V.G Kukes. M.: GEOTAR-Media, 2013. $1056 \mathrm{~S}$.

34. Clinical guidelines Diagnosis and treatment of arterial hypertension Ministry of Health of the Russian Federation, Moscow 2013

35. Kobalava, Z. D., Kotovskaya Yu. V., Moiseev V. S. Arterial hypertension. The keys to diagnosis and treatment: the Series "Library medical specialist". M.: GEOTAR-Media, 2009. 864 p.

36. Medvedev I. N., Kumova, T. A., Gamolina 0. V. Role of the reninangiotensin- aldosterone system in the development of arterial hypertension // Russian journal of cardiology. 2009. No. 4. S. 82-84

37. Mukhin N. And., Moiseev V. S., J. D. Kobalava and Cardiorenal etc. interaction: clinical significance and role in pathogenesis diseases of the cardiovascular system and kidneys // Ter. archive. 2004. No. 6. P. 39-47.

38. Nedogoda S. V., Tsoma V. V., Chalabi T. A., Brel, U. A., Mazin G. V. Comtional efficiency of original and generic losartan in patients with essential hypertension // cardiovascular therapy and prevention, 2007, No. $6, \mathrm{pp} .10-14$

39. Ostroumova O. D., Maksimov M. L. the Choice of a combination of inhibitors ACE and diuretics in the treatment of arterial hypertension in new the Russian edition of the recommendations: focus on treatment of elderly patients // Farmateka. 2011. No. 8. S. 42-49 
40. Ostroumova O. D., Maksimov M. L. the Place of angiotensin- converting enzyme in treatment of hypertension in different groups of patients // cardiovascular therapy and prevention. 2010. No. 9 (7). S. 90-96.

41. Federal clinical recommendations on the use of the method spirometry // Russian respiratory society, Moscow -2013.

42. Khabriev R.U., Kulikov A.Yu., Arinina E.E. Methodological basis of pharmacoeconomic analysis. Moscow: publisher "Medicine", 2011. 128 pages.

43. The Ministry of health of the Russian Federation "Diagnosis and treatment of hypertension" clinical guidelines Moscow 2013

44. Konradi A. 0. ACE Inhibitor Fosinopril in the treatment of arterial hypertension - the potential benefits of St.-Petersburg 2014

45. Yagudina R.I., Kulikov A.Yu., Ugrekhelidze D.T. Assessing willingness-topay threshold for health technologies in the Russian Federation on the basis of purchasing power parity // Pharmacoeconomics: theory and practice. - 2015. - Vol.3, №3. - P.10-14 